\title{
ARE PROJECTS CHANGING PUBLIC SERVANTS INTO PROJECTARIANS? PROJECTIFICATION'S INFLUENCE ON EMPLOYEES IN THE POLISH PUBLIC SECTOR*
}

\author{
Beata Jałocha**
}

\begin{abstract}
Background. Projects pervade public organisations and influence the way they solve complex and complicated social and organisational problems. The consequnce of the poliferation of projecs is called projectification: more and more activities are being transformed into projects. Projectification also seems to change significantly the situation of public servants, and not only the organisations. They are expected to assume the dual role of a public servant and of the project/portfolio/programme manager/project team member.
\end{abstract}

Research aims. The aim of this paper is to address the research problem concerning the influence of projectification processes on public servants in Poland.

Methodology. The paper is of a conceptual character (based on literature review), although it is also illustrated by an empirical example.

Key findings. The employees of public organisations perceive themselves as public servants in the first place, not as project managers or project workers. Although project work has an impact on the ethos of their work, it seems that it does not harm or influence their professional identity: they remain public sector servants in their opinion. However, considering the relatively low salaries in the Polish public sector, the temporariness of their employment and stress related to project work, public servants may be in danger of becoming in the future the projectariat - the precariat class of project workers in the public sector.

Keywords: projectification, projectariat, public servants.

* Acknowledgements: Beata Jałocha has prepared this publication as a result of the research project registered under No. 2016/23/D/HS4/01810 and financed from the funds of the National Science Centre, Poland.

** Jagiellonian University. E-mail: beata.jalocha@uj.edu.pl 
In times of interregnum (Bauman, 2002) characterised by an increasing sense of insecurity, we observe a huge change of the world around us, but we do not know the direction of this change. Monika Kostera (2014) argues that the omnipresence of organisations and destabilisation of organised social life characterises today's world. Obviously, these changes affect the public sector, too. During the last decades, undoubtedly the strongest mark on the method of public affairs management in many countries around the world was imprinted by New Public Management (Belfiore, 2004; Protherough \& Pick, 2002). It introduced a completely new concept of how the public sector should function everywhere around the world. It brought fascination with business methods and at the same time, eroded good citizenship and replaced it with clientelism. The main idea of NPM is to make public organisations, as well as their employees, much more 'business-like' and 'market-oriented'. However, it is more and more frequently noticed that NPM has serious negative consequences for the public sector that outnumber the positive outcomes. According to Diefenbach (2009), NPM has led to a deterioration of the corporate culture, the traditional work ethos and non-functional values in many public organisations.

One of the methods that is frequently used by the public sector to implement its policies is project management. Projects pervade public organisations and influence the way they solve complex and complicated social and organisational problems. The consequnce of the poliferation of projecs is called projectification: more and more activities are being transformed into projects. Projectification also seems to change significantly the situation of public servants, and not only the organisations. They are expected to assume the dual role of a public servant and of the project/portfolio/programme manager/project team member. Public servants assuming the role of project managers adopt the body of knowledge of professional project methodologies as the basis for their actions (Fred \& Hall, 2017). At the same time, they are subject to specific rules governing public organisations. This means that they are subject to separate guidelines, as in the case of other project managers operating in various organisations. Hodgson and Paton (2016, p. 354) write that "project managers are torn between affiliation with the 'rock' of their profession or the 'hard place' of their employer" - the same goes for the public sector. In addition, as a result of projectification, procedures used by them so far, which have often 
been aimed at achieving long-term goals, change dramatically and become reduced to short-term actions. Does that mean that public servants implementing their task in a new projectified reality become a projectariat - a group of clerks forming the precariat of the public sector due to the omnipresent project work? These questions will be considered in this paper. The aim of this paper is therefore to address the research problem concerning the possible influence of projectification processes on public servants in Poland.

In order to discuss the possible impact projectification has on Polish public servants, I will start by describing the projectification processes in the public sector. Then I will focus on the ethos of public services, which changes as a result of projectification. In the further part, I will refer to the subject of precariat. Then I will discuss the concept of projectariat. The next chapters discuss the empirical illustration of the phenomena. The paper finishes with a discussion and concluding remarks regarding future research.

\section{PROJECTIFICATION OF THE PUBLIC SECTOR}

Although it may seem that the public sector has just adapted business project management practices to its needs on the wave of the NPM, it is not completely true. As the history of project management shows, the public sector had developed a number of tools that later entered the project management toolbox in all sectors. For example, the principles of systematic project management, project maturity models, project techniques were all firstly developed in the public sector (Gasik, 2017). However, it seems that massive projectification firstly began in the private and not the public sector.

Projectification (Midler, 1995) can be understood in a narrow and broad way. Packendorff and Lindgren (2014), who introduced a distinction between narrow and broad conceptualisations of projectification, extended the understanding of projectification from its concern with the "increased primacy of projects in contemporary organisational structures into an interest for cultural and discursive processes in a society in which notions of projects are invoked" (Packendorff \& Lindgren, 2014, p. 7). Therefore, we can also understand it as a specific meta-phenomenon, permeating all activities in modern societies. 
In the public sector, as Mats Fred (2018, p. 189) indicates:

Projectification as proliferation emphasises the increasing use and diffusion of projects and project ideas; projectification as transformation and adaptation highlights processes of transformation of "permanent" ordinary organisational activities to temporary projects, and processes of adaptation in the surrounding organizations and structures; and projectification as organisational capacity building in which the project logic is spread and diffused in local government organisations, not primarily through specific projects, but through practices encouraging the project logic, and how that reinforces local government's organisational project capacity.

Although there are different reasons of project proliferation in the public sector (Sjöblom, 2006) projectification of the public sector is a phenomenon that pervades public policies, organisations and influences the working conditions of people working there. According to Schoper et al. (2017), approximately one third of all tasks is implemented in the form of projects. These authors in their research on the degree of projectification in three European countries (Norway, Iceland, and Germany), point out that in all of these countries the degree of the public sector's projectification, understood as a percentage representation of project tasks in relation to the whole work performed in a given sector, is very high. In Iceland it is $33.3 \%, 17.8 \%$ in Germany, and $14.2 \%$ in Norway. Taking into account the fact that the public sector's tasks are mainly based on rendering repeatable services to the society, it is a very high percentage of "projectification". There is no such research related to the public sector in Poland, but we may expect a similar indicator, based on the number and size of EU funded public projects in Poland (Prawelska-Skrzypek \& Jałocha, 2014).

In EU countries, project management is one of the major instruments for implementing the structural fund policies of the European Union (Sjöblom et al., 2013). Public organisations use increasingly often the language of projects, nomenclature, and vocabulary borrowed from the field of project management for communication with the external world. More importantly, thinking about office activities turns into "project thinking", which is based on the planning of short projects limited by certain frameworks that do not always form a long-term plan of the organisation's activities and work in favour of stakeholders. As Baur et al. (2018, p. 348) indicate, the project's specific feature in comparison to other organisational forms is that 
"it organizes endeavours that are both substantially and temporally limited." The time and subject limitation of the public tasks being implemented must influence the way in which the public sector plans and implements its tasks. Projects do not seem to be a solution, which would enable management in a continuous and overall way, however, as practice shows - they are considered to be the universal remedy for every social and economic problem. It seems that projectification of the public sector consists of two parallel processes. The first one is based on searching for effective forms of implementation and coordination of public policies, and the second - looking for immediate solutions for solving complex public projects. Such assumptions are catalysts of the process of public sector projectification.

\section{PROJECTIFICATION VS. THE ETHOS OF THE POLISH PUBLIC SECTOR}

When Monica Lindgren and Johann Packendorf (2007) wrote ten years ago that projectification was becoming an everyday matter in an increasing number of organisations, Polish offices were only beginning to learn this phenomenon. Three years after entering the structures of the European Union, these organisations were starting their big adventure with projects. Even though post-socialist reforms that began in Poland after 1989 were already implemented largely in the form of projects (or the method of their organisation was based on the rules of project work) (Dornish, 2002, p. 309), it was only the accession to the EU that triggered a real project boom. According to the data of the Ministry of Regional Development, 153,557 projects were implemented in Poland with financial support from the European Union in the years 2004-2011. According to the financial perspective for the years 2007-2013, Poland became the biggest beneficiary of funds among all EU member states (Prawelska-Skrzypek \& Jałocha, 2014).

Imre Kovách and Eva Kučerová (2009) writing about "project class" emerging in the Czech Republic and Hungary, propose the thesis that project management is one of the tools affecting significantly the integration of European structures. While agreeing with them, we cannot ignore the fact that the projectification of Polish local government entities creates not only management problems, but also certain structural problems on the operational level. Even though the 
subjectivity and independence of Polish offices is guaranteed by the constitution, projectification results in the subordination of development goals of public organisations, regions, or even the country to supreme goals imposed by the institution providing financial resources. Thus, Polish public organisations fulfil heteronomous goals through projects (i.e., goals imposed from the outside rather than determined by them). By accepting this, they have a chance to obtain external funds to finance their development goals. The lack of independence of public organisations manifests itself not only through their agreement to the implementation of projects the goals of which are determined outside the organisation concerned and to the creation of pseudo-portfolios of projects where critical selection actually does not exist. They also agree to the adoption of methods of project management, implementation, and settlement. Very specific roles must also be fulfilled by project managers and project team members. However, it is not only the Polish case - Mats Fred (2014) notices that one of the aspects of the politicisation of the public project financing system is that projects financed by EU are created not on the basis of locally diagnosed problems that require a solution, but by financial agencies on a higher level. It is local needs that have to be adapted to frameworks imposed from the top, not vice versa. This means in practice that European polities have a direct impact on how local servants work every day (Fred, 2014). People who are engaged in project activities are controlled to an even larger extent - e.g., in terms of time, place, and mindset (Lindgren \& Packendorff, 2007). Thus, the situation of public servants is specific - apart from compliance with restrictive work requirements in the public sector, regulations, laws, and bureaucracy, they are also subjected to further restriction resulting from project work (e.g. the necessity to follow project management methodologies).

Moreover, the ongoing changes affect also the ethos of public service. Market-oriented public administration created a specific ethos based on the belief about the central position of the citizen, who is perceived as a customer towards the public service organisation. NPM is characterised by a market-oriented approach to the ethos of public service. It draws upon neoliberal concepts that propose the introduction of management rules and mechanisms into the public sector (e.g., economisation, privatisation, deregulation, debureaucratisation, contracting for public services, the outcome-oriented approach, and focus on quality). In this case, the essence of a public servant's ethical behaviour lies in effective 
and efficient action based on economic rationality and maximisation of the quality of offered services. A public servant becomes a manager who maximises the usefulness of resources in use and renders public services effectively and efficiently. In Poland, because of historical processes, various approaches to the ethos of public service co-exist beside one another. Until the state regained independence in 1989, the ethos had been based only on a bureaucratic approach (highlighting technocratic and procedural values, where a servant's excellence is measured by his/her ability to comply literally with laws, regulations, and instructions), but the introduction of reforms brought also elements of public management and the community ethos (based on intersector partnership, participation, joint responsibility, and inclusiveness). Such a heterogeneous ethos of public service creates mutually exclusive pressure from the environment that public servants must carry on their shoulders (Mazur, 2012), at the same time being charged with the growing scale of projectification. Being attached most strongly to the bureaucratic model and the associate labour system based on secure and stable employment and the performance of repetitive activities, they become immersed in the wave of projectification.

\section{"PRECARITY IS EVERYWHERE"}

The concept of precariat originates from the works by Pierre Bordieu, who described precarity as a "new mode of dominance" resulting from restructuring of the economy that "forced workers into submission" (Choonara, 2011). Bourdieu thought that the globalisation and fragmentation of the labour market created a permanent sense of insecurity among employees. This view was presented as the guiding idea in the book The Precariat: The New Dangerous Class by Guy Standing (2011). According to Guy Standing, precariat consists of persons employed under flexible labour relations, not under permanent employment contracts concluded for an indefinite period. In his book, Standing emphasises the fact that precariat as a new kind of social class is an increasing group of people devoid of essential guarantees of employment, which has an adverse effect on their welfare and living conditions. The characteristic qualities of precariat mentioned by Guy Standing include instability of employment, a lack of professional identity, and performance of work below one's qualifications and outside (normal) 
working hours. In addition, members of the precariat class have more difficult access to pension, sickness, and parent benefits. Consequently, they are subject to the progressive loss of their political and social rights. According to Standing, precariat encompasses only certain parts of professional groups.

"Precarity is everywhere" - these words expressed by Pierre Bordieu can also be referred to the public sector (Tschöll, 2014). According to Choonara (2011), many public sector workers rightly feel threatened by the growing privatisation of public services by both government and local councils. Until recently, the public sector has been a place where it was possible to find a stable job even during a crisis period. For many years, it guaranteed fixed remuneration, social security (holidays, sickness, and maternity benefits), work at a fixed place and during fixed hours. Temporary employment for the period of EU projects is characterised by a limited time of employment and a specific relationship between the employee and the employer. Even though the employee is employed by a public organisation, he/she often does not take advantage of the terms of employment according to the same rules as in the case of persons whose work is financed from the state budget. This is due to the fact that, under a majority of EU programmes, employees implementing projects must not receive, e.g., a performance bonus or the annual bonus for good performance to which public servants in Poland are usually entitled. Conditions characterising the work of the precariat class, to which temporary project workers are subject in the public sector, include also low remuneration (the EU specifies clearly maximum remuneration rates in projects for a given country, which are considerably lower in Poland than in Western European countries), a lack of protection against the ceasing of employment (the project ends on a strictly defined date), and a lack of access to welfare and additional benefits available to public servants employed for an indefinite period (bonuses, extra remuneration). By imposing project work on countries such as Poland, the European Union stimulates the development of McJobs in the public sector in a certain way. According to the data of the Central Statistical Office (GUS), 638,600 persons were employed in the public administration sector, including national defence and social security, in 2013. A large group of public servants was employed in connection with the management and settlement of EU funds. Announcements suggest that Poland will receive much lower funds from the EU after 2020. The problem of dismissals will affect at 
least several thousand public servants. The people who have worked on the implementation of European funds since the beginning, have a huge knowledge and were trained in terms of EU funds will lose their jobs (Dyl, 2016). This may be a tremendous change in the case of public servants who are more likely to attach high value to an interesting job and job security according to surveys. Public service employees are also more intrinsically motivated than their non-public service counterparts and attach higher value to job security (Houston, 2014).

\section{PROJECTARIAT - THE CONCEPT AND ITS ORIGINS}

It may be said that precarity of the work conditions has in a sense been always existing, mainly in relation to unprivileged groups. At the same time, the ongoing projectification processes have introduced significant changes to the way in which people perform work. We may apply the term projectariat to employees, who by performing work within the framework of projects, experience precarious work conditions. It is because projects have become the "Trojan horse", through which precarious work conditions were introduced into the organisation.

In 2015, the article by Ada Banaszak, was published in the NN6T journal. The article had a telling title "Projektariat ma dość!" ("Projectariat has had enough!") and it discussed the situation experienced by employees of NGOs, involved with project work, which does not give them a feeling of economic and social stability (Banaszak, 2015). This text corresponded with the reflections I had after carrying out initial research on the condition of public officials in Polish local government organisations. Soon afterwards the book by Kuba Szreder (2016) entitled $A B C$ projektariatu ("The $\mathrm{ABC}$ of Projectariat") appeared, which discussed the situation of the precarious employees of culture. Szreder attributes the authorship of the term "projectariat" to Szymon Żydek who used it in a private talk about the situation of people involved in the Arts. If we follow the literature carefully we will find, however, an earlier text in which Catherine Baker used the term "projectariat" in order to describe a group of local workers employed by aid organisations in the countries of the former Yugoslavia, for the period of project duration (Baker, 2014).

Catherine Baker (2014) described projectariat in a text about the situation of local workers employed in projects during a peace 
mission in former Yugoslav countries. The researcher illustrates the notion of projectariat as exemplified by the local citizens, employed as translators in peace mission projects. The main reason for insecurity of this group of workers was that their whole employment was based on project work, limited by short contracts concluded for the time of aid project implementation (Baker, 2014). Moreover, although some of the aid organisations declared upfront that they intend to stay in the country for a longer, predefined time, many of them were not able to say for how long they would stay and ensure work to the people they had employed. This meant that the translators had no idea how long their employment would last - whether it would definitely end with the project or its nature would be more long-term. What motivated the workers being described to undertake work in the aid projects all the same stemmed out from the difficult situation faced by people in countries healing their post-war wounds. Baker, by evoking biographical interviews, which she had conducted with the translators, tells in a more detailed way about the causes and consequences of undertaking work by them. Willingness to help parents, repair the real estates, which had been destroyed during the war, support for the family, possibility to pay for medical care, finding a job, which could ensure a safe living situation to their children, raising funds to move to a more economically stable country - are only some of the reasons indicated by the translators as the reason for their willingness to undertake work in aid projects (Baker, 2014, p. 94). This employment, however, was connected with consent to a number of precarious work conditions: no or minimum sickness and maternity benefits, possibility to terminate the contract within one month or even a shorter notice period, risk of injuries that the translators, travelling in a post-war country with peace mission troops, faced.

At the same time, Baker notices that the situation of the projectariat, which she describes, was not completely unambiguous. On the one hand had they experienced a number of problems connected with the precarity of the work they were performing in the framework of the projects. On the other hand - they were the elite group of the "chosen ones" who thanks to the acquired job could change their social situation. Against the background of the post-war, very difficult economic situation, they were in a sense privileged: they had the opportunity to receive higher wages and to develop skills acquired while working for peacekeeping organisations. As it is emphasised by Baker, the choice 
of such form of work was not really a choice, but a necessity: "People typically began working for international organizations because it was the only work available or the highest-paying work available, or because the war and its aftermath had made it impossible for them to fulfil their pre-war career intentions" (Baker, 2014, p. 101). Thus, it may be noticed that the way in which aid policy is conducted in war-torn countries, namely through projects, may strengthen the negative effects of projectification processes.

Szreder (2016) in his book which he devoted to the practice of project work in culture, also describes the projectarians. Their situation is seemingly totally different than the situation of the local employees of aid organisations described by Baker. They have not experienced war, they are usually educated, they belong to the country's intellectual elite - they are artists, curators, an arts people. What links these two groups is dependency and subjection to project-type work conditions. Szreder defines projectariat as a group of people who "have nothing except their readiness to join in a project." This author refers to the artistic environment, discusses the practices of implementing projects in culture, in which since times immemorial there has been a specific consent to deprecation of the material needs of the artists. The precarity of work in creating art is taken for granted - the artist is supposed to create and not to deal with gaining wealth. What is more, it may be said that there is general acceptance for the artists' poverty. Szreder describes how project work enhances and legitimises the consent to work precarity in the culture sector.

It may be noticed that the works of the said authors pointed out the situation of injustice and oppressiveness of project work at the level of the individuals caught up in it. Project freedom has led us to a specific "liminal space", in which one part of the employees are stuck in hope for a better future, and the other part - due to a lack of choice and chance to return to the previous way of acting. However, it cannot be stated that project work always means precarity. Nonetheless, it is worthwhile to take a look at those groups which up till now have been perceived as the most stable ones as regards work safety - civil servants. In the further part of the deliberations, I will give consideration to the question whether a part of the officials, taking into account their involvement in project work, may be included in the group that we call projectariat. 


\section{EMPIRICAL ILLUSTRATION: CIVIL SERVANTS AND PROJECTIFICATION}

This paper is based on a literature review, however to illustrate the conceptual deliberations with empirical example, I would like to present some preliminary qualitative research results conducted in Polish public organisations. The empirical illustration presented below is based on a preliminary fragmentary results obtained on the basis of 4 in-depth semi structured interviews - the empirical research is currently being developed within the framework of a broader research project on projectification of Polish public sector. Although the research sample is not large and the results cannot be generalised it may be an interesting illustration to the issue I am discussing in this paper.

The interview protocol that I used contained a number of questions structured around two sections, which are the research questions:

How does projectification influence public servants' day-to-day activities and work conditions? How do public servants understand their professional role in projectified organisations?

These interviews were conducted with civil servants working in Polish public organisations. Their choice was snow-ball sampling inspired: the first interviewee recommended me the next one etc. All four research participants were project managers or had project management responsibilities. All participants were experienced in project work - all of them had been involved in project activities for at least 10 years. All participants were employed in public organisations, although these were various types of organisations - one person worked in a city culture centre, one was employed in a commune office in a small location on the outskirts of a big city, and two worked in a provincial labour office. The interviews were recorded, transcribed and then coded according to themes developed inductively from the empirical material itself. The transcripts were read through to reveal emerging topics. I am aware of the fact that the results are limited, however, my intention was not to generalise the results. The qualitative research I used was intended to open the discussion on the working conditions of public servants involved in project work and to give them voice, enable them to express their opinions about working in a projectified public sector. 
The way the participants reflected on their experiences in project management in the world of public organisations was very interesting to observe. When asking civil servants how they handle projects on an everyday basis, we can notice a sort of acceptance of this form of performance of tasks and this method of work. Project management is no longer an innovation - a mysterious ceremony practiced by a small group of chosen ones in public organisations at the beginning of the $21^{\text {st }}$ century (Jałocha, 2014). Projectification has become an everyday issue:

This is practice. Projects don't actually differ much from one another. We're no longer desperate, frightened, or discouraged. We simply do what we have to do. There's no rebellion in us any longer. You can't circumvent it - these are public funds, which must be settled. (Public Servant 1)

There were also opinions that supreme authorities and central offices await or sometimes even enforce intense implementation of projects:

Employees are expected to carry out projects. These expectations are not expressed by the management, but by the city authorities that finance our activities. In our reports, we often have to write where we applied for financial aid, what amount of financial aid we expected, what we have already achieved and what kind of support we would expect from the city. The city keeps examining how many projects have been implemented, which of them were co-financed and which were not. (Public Servant 1)

The respondents also stressed that, in spite of performing project work every day, they feel that it restricts their creativity:

The project cycle is very short and limited and does not allow you to be more creative. Something that is planned must be carried out and there is no room for implementing our own ideas in EU projects. There are limitations: the project, specific provisions, budgets, reporting. (Public Servant 1)

I think that projects serve more specific actions, because we have to detail their goals very precisely when writing a project. And in the case of cyclic operations, such as Slajdowisko, they don't have any specific aim - they make people relaxed and more satisfied on their way home. If this goal was to be translated into a project application, it would be absolutely insufficient for someone who is evaluating it. Pleasure or happiness is not usually the goal of projects, and we will not obtain money for such projects. (Public Servant 2) 
However, respondents also said that, in spite of the impossibility of undertaking creative activities, the implementation of projects always requires certain skills, characteristics, and attitudes that are not always required in normal clerical work.

Project work must be entrusted to persons who are not afraid of difficulties and can solve problems. In ordinary routine clerical work, it is often sufficient to be scrupulous and dilligent. In the case of projects, problems arise almost every day. (Public Servant 3)

Project work is also considered to be a stressful experience:

The very fact that the project has a deadline and has to be completed on time and there are fears about getting funds is stressful. When we get a project, the biggest stress starts because we have to do everything that we described for a certain amount.

This is followed by stress connected with settlement. Stress certainly accompanies us in our project work and affects our behaviour and the atmosphere in the office at a given moment. The closer the deadline, the more nervous everyone becomes - sometimes there are quarrels within the team. (Public Servant 1)

The respondents also referred to the fact that project work penetrates into their private lives.

I hit upon ideas in my spare time, at home. Project work is with you 24 hours a day. (Public Servant 4)

Interviews conducted with public servants responsible for projects show that project work often fails to give them a sense of security with regard to job stability and guarantee of employment. However, fears of the future are expressed by the public servants whose employment depends on EU grants:

Now, this involves risk. After the completion of the project, you don't know if there are any new project opportunities, because everything depends on the source of financing. My situation is insecure and I take this insecurity into account. When someone is a younger employee and has a contract concluded for the period of the project, his/her stress is even bigger. I can receive a notice of termination, so I have some time to look for a new job, and others' contracts end because the project ends. And these persons simply do not come to work on the next day. This may seem obvious, but it isn't easy. (Public Servant 3) 
On the one hand, project work makes you visible - you can prove your skills and competence. On the other hand, you can never be sure that there will be something to do later. I'm employed for an indefinite period, because that's how an employment contract has to be concluded in accordance with the Polish law. I'm delegated to the project and I have new financial terms agreed upon for the time of the project. Then I move to another project, or I can return to my previous job position. But I began to work there 10 years ago and now my job position simply doesn't exist anymore. (Public Servant 4)

This tension and insecurity is absent from opinions expressed by a public servant from a small commune office. This may be caused by the fact that such offices are less projectified - projects are an additional activity rather than the main type of tasks there. Therefore, the rules of work are relatively similar to tasks performed before the age of projectification.

There is no sense of insecurity in our office. 100\% of persons are employed under an employment contract. The biggest stress is connected with project management in the Provincial Labour Office, the Marshal's Office, and in the Krakow Metropolis in 7 years' time, when projects from the EU come to an end.

In the Marshal's Office, $80 \%$ of public servants' salaries are financed by the EU. When this ends, a part of the people will have to leave. (Public Servant 2)

Control related to project work is described by the respondents as something greater than in the case of standard work:

In projects, there is a double level of control. This is a part of project management. (Public Servant 3)

I feel controlled more intensively in projects - this results from external control. Achievement of results, indexes, public procurement orders. (Public Servant 2)

I don't like control in projects, because I write 6 different reports at the end of the year, and each contains the same things, but is addressed to a different office. (Public Servant 4)

When asked about their professional identity, i.e., who they feel they are, all respondents answered that they are public servants. Even though they have carried out projects for many years, none 
of the persons considers himself/herself to be a project manager or a project team member.

I definitely feel that I am a public servant rather than a project manager. (Public Servant 2)

First of all, we are public servants - someone who has been entrusted with the implementation of public purposes, and the project is the method of implementing these purposes. (Public Servant 3)

Is it a question of the ethos of public service rooted deeply in respondents' professional attitudes? Other studies (Paton et al., 2010) show that being a project manager is usually another career stage in respect of being a representative of another profession. Project managers are professionals who usually have a different professional background; this happens because employees perceive management as new attractive career development opportunities, but they are still strongly attached to their original profession. Moreover in this case, all of my respondents had become public servants at first, and only later did they engage in project work.

\section{CONCLUDING DISCUSSION AND FURTHER RESEARCH}

In many public organisations, "NPM has led to a deterioration of the corporate culture, traditional work ethos, and non-functional values" (Diefenbach, 2009). Stress, higher requirements, excessive control - all of these factors are experienced by public servants engaged in project work in their workplace, although they also characterise work conditions of project managers in other industries (Asquin et al., 2010). The change of the method of performance of tasks by public organisations and the adoption of the project as the primary form of performance of tasks has an impact on work conditions of at least part of public servants. However, this impact seems to be varied.

Projects change the way public servants in Poland work, but it does not always have a direct influence on their formal work conditions (contracts). The influence of projectification is visible in regard to how they perform their activities, which is not always mirrored by the contracts they sign. Projects have forced some public servants to 
adopt "project-based thinking", but they did not change the formal conditions of their employment. As public servants, they have permanent employment guaranteed in the form of employment contracts for an indefinite period. However, there is also a crowd of public servants who are employed for a definite period, i.e. for the duration of projects. This trend of temporal project employment is visible in many sectors - for example in the non-governmental sector (Szreder, 2016) and at universities (Baur et al., 2018). However, considering the relatively low salaries in the Polish public sector, the temporariness of their employment and stress related to project work, they may be in danger of becoming in the future the projectariat - the precariat class of project workers in the public sector.

The employees of public organisations perceive themselves as public servants in the first place, not as project managers or project workers. Although project work has an impact on the ethos of their work, it seems that it does not harm or influence their professional identity: they remain public sector servants in their opinion.

Independent of how the officials perceive their work, it seems that the change is permanent and projectification has altered the image of Polish offices for ever. But what if we are wrong - if public organisations are autopoietic systems, if the changes that we consider to be permanent and profound, such as the projectification of this sector, are also temporary, transitory and reversible? It is assumed, also after the analysis of projectification, that organisations are open systems engaged in constant exchange with the surrounding environment and adapting continuously to environment changes, depending on whether they are able to adapt (Ackoff, 1971). The belief that reforms of the public sector and the introduction of new management solutions, including management by projects, lead to a permanent organisational change is also based on this assumption. According to the theory of autopoietic systems, living (biological) and social systems (e.g. human organisations) are open and enter into reactions with their own environment, but they are also operationally closed, subordinating all interactions to the key internal process called aoutopoiesis (Lenartowicz, 2015). Thus, interactions of the system (organisation) with the outer environment occur only to such an extent that the system is able to reproduce its own established patterns.

So, do changes resulting from projects happen for real? What impact do they have on public servants? Will the employees who clearly 
consider themselves to be public servants make attempts to return to the established path of bureaucracy when the stream of EU project funds ceases to flow? These are only some of the questions that it would be worthwhile to consider in further research on the impact of the projectification processes on the public sector in Poland.

\section{REFERENCES}

Ackoff, R.L. (1971). Towards a system of systems concepts. Management Science, 17(11), 661-671.

Asquin, A., Garel, G., \& Picq, T. (2010). When project-based management causes distress at work. International Journal of Project Management, 28(2), 166-172.

Baker, C. (2014). The local workforce of international intervention in the Yugoslav successor states: 'Precariat' or 'projectariat'? Towards an agenda for future research. International Peacekeeping, 21(1), 91-106.

Banaszak, A. (2015). Projektariat ma dość! NN6T Notes Na 6 Tygodni, http://notesna6tygodni.pl/?q=projektariat-ma-do\%C5\%9B\%C4\%87 (accessed: $12^{\text {th }}$ Dec 2015).

Bauman, Z. (2000). Liquid Modernity. Cambridge: Polity Press.

Baur, N., Besio, C., \& Norkus, M. (2018). Projectification of science as an organizational innovation: A figurational sociological perspective on emergence, diffusion and impact. In: W. Rammert, A. Windeler, H. Knoblauch, \& M. Hutter (eds.), Innovation Society Today: Perspectives, Fields, and Cases (pp. 341-370). Wiesbaden: Springer.

Belfiore, E. (2004). Auditing culture: The subsidised cultural sector in the new public management. International Journal of Cultural Policy, 10(2), 183-202.

Choonara, E. (2011). Is there a precariat? Socialist Review, October (362).

Diefenbach, T. (2009). New public management in public sector organizations: The dark sides of managerialistic "enlightenment." Public Administration, 87(4), 892-909.

Dornish, D. (2002). The evolution of post-socialist projects: Trajectory shift and transitional capacity in a Polish region. Regional Studies, 36(3), 307-321.

Dyl, B. (2016). Urzędnicy obstugujacy fundusze unijne straca pracę, http://www. portalsamorzadowy.pl/drukuj/69370.html (accessed: 10 ${ }^{\text {th }}$ Dec 2015).

Fred, M. (2014). Porous Organizing: Making Sense of Projectification in Swedish Municipalities, $7^{\text {th }}$ Making Project Critical workshop, Stockholm: KTH Royal Institute of Technology.

Fred, M. (2018). Projectification: The Trojan horse of local government. Doctoral dissertation. Lund University/Malmo University. 
Fred, M. \& Hall, P. (2017). A projectified public administration: How projects in Swedish local governments become instruments for political and managerial concerns. Statsvetenskaplig tidskrift, 119(1), 185-205.

Gasik, S. (2017). Zarzqdzanie projektami sektora publicznego. Warszawa: Akademia Finansów i Biznesu Vistula.

Hodgson, D. \& Cicmil, S. (eds.) (2005). Making Projects Critical. London: Palgrave Macmillan.

Hodgson, D.E. \& Paton, S. (2016). Understanding the professional project manager: Cosmopolitans, locals and identity work. International Journal of Project Management, 34(2), 352-364.

Houston, D.J. (2014). Public service motivation in the post-communist state. Public Administration, 92(4), 843-860.

Jałocha, B. (2014). Zarzadzanie portfelem projektów. Koncepcje biznesowe a praktyka organizacji publicznych. Kraków: Wydawnictwo Uniwersytetu Jagiellońskiego.

Kostera, M. (2014). Occupy Management: Inspirations and Ideas for Self-Organization and Self-Management. London \& New York: Routledge.

Kovách I., Kučerová E. (2009). The social context of project proliferation: The rise of a project class Journal of Environmental Policy and Planning, 11(3), 203-221.

Lenartowicz, M. (2015). The nature of the university. Higher Education, 69(6), 947-961.

Lindgren, M. \& Packendorff, J. (2007). Performing arts and the art of performing On co-construction of project work and professional identities in theatres. International Journal of Project Management, 25(4), 354-364.

Mazur, S. (2012). Etos służby publicznej i jego oblicza. In: S. Mazur (ed.), Jaki etos $w$ administracji - stużba publiczna, menedżerski profesjonalizm czy przestrzeganie procedur? (pp. 9-17). Gdańsk: Instytut Badań nad Gospodarka Rynkowa.

Midler, C. (1995). "Projectification" of the firm: The Renault case. Scandinavian Journal of Management, 11(4), 363-375.

Packendorff, J. \& Lindgren, M. (2014). Projectification and its consequences: Narrow and broad conceptualisations. South African Journal of Economic and Management, 17(1).

Paton, S., Hodgson, D., \& Cicmil, S. (2010). Who am I and what am I doing here? Becoming and being a project manager. Journal of Management Development, 29(2), 157-166.

Prawelska-Skrzypek, G. \& Jałocha, B. (2014). Projektyzacja sektora publicznego w Polsce - implikacje dla organizacji. Zarzqdzanie Publiczne, 3(27), 273-285.

Protherough, R. \& Pick, J. (2002). Managing Britannia: Culture and Management in Modern Britain. Harleston, Norfolk: Edgeways. 
Schoper, Y., Wald, A., Ingason, H.T., \& Friðgeirsson, T.V. (2017). Projectification in Western economies: A comparative study of Germany, Norway and Iceland. International Journal of Project Management, 36(1), 71-82.

Sjöblom, S. (2006). Introduction: Towards a projectified public sector: Project profileration as a phenomenon. In: S. Sjöblom (ed.), Project Proliferation and Governance: The Case of Finland (pp. 9-31). Helsinki: Swedish school of social science, University of Helsinki.

Sjöblom, S., Löfgren, K., \& Godenhjelm, S. (2013). Projectified politics - temporary organisations in a public context. Scandinavian Journal of Public Administration, 17(2), 3-12.

Standing, G. (2011). The Precariat: The New Dangerous Class. London \& New York: Bloomsbury Academic.

Szreder, K. (2016). ABC projektariatu. O nędzy projektowego życia. Warszawa: Bęc Zmiana.

Tschöll, C. (2014). Precarity: Causes, effects and consequences of insecure working and living conditions in a multicultural, rural area of northern Italy (South Tyrol). Journal of Education Culture and Society, 2, 82-90. 


\title{
CZY PROJEKTY ZAMIENIAJA URZĘDNIKÓW W PROJEKTARIUSZY? WPKYW PROJEKTYZACJI NA PRACOWNIKÓW POLSKIEGO SEKTORA PUBLICZNEGO
}

\begin{abstract}
Abstrakt
Tło badań. Projekty przenikaja organizacje publiczne i wpływają na to, jak rozwiązywane są złożone i skomplikowane problemy społeczne oraz organizacyjne. Konsekwencją rozpowszechnienia projektów jest zjawisko projektyzacji, polegające na transformacji coraz większej liczby aktywności w projekty. Wydaje się, że projektyzacja zmienia nie tylko sytuację organizacji publicznych, ale także urzędników w nich pracujacych. Oczekuje się bowiem od nich podejmowania podwójnej roli urzędnika publicznego i kierownika projektu/portfela/programu czy też członka zespołu projektowego.
\end{abstract}

Cel badań. Celem artykułu jest podjęcie dyskusji nad problemem badawczym dotyczącym wpływu procesu projektyzacji na urzędników publicznych w Polsce.

Methodologia. Artykuł ma charakter koncepcyjny, bazuje na przeglądzie literatury przedmiotu. W artykule zawarto ponadto ilustrację empiryczna, opartą na wstępnych badaniach o charakterze jakościowym.

Kluczowe wnioski. Pracownicy organizacji publicznych zaangażowani w prace projektowa postrzegają siebie przede wszystkim jako urzędników, a nie kierowników projektów czy też pracowników projektowych. Mimo że praca projektowa oddziałuje na etos ich pracy, wydaje się, że nie ma większego wpływu na ich tożsamość zawodową. Jednocześnie - biorąc pod uwagę relatywnie niskie płace w polskim sektorze publicznym, tymczasowość zatrudnienia w projektach oraz stres związany z zadaniami projektowymi - istnieje zagrożenie, że urzędnicy pracujacy przy projektach w przyszłości będą mogli stać się projektariuszami - klasą prekariuszy zatrudnionych w projektach sektora publicznego.

Słowa kluczowe: projektyzacja, projektariat, urzędnicy publiczni. 